Egyptian Journal of Aquatic Biology \& Fisheries

Zoology Department, Faculty of Science,

Ain Shams University, Cairo, Egypt.

ISSN $1110-6131$

Vol. 25(4): 1 - 13 (2021)

www.ejabf.journals.ekb.eg

\title{
Some Physical and Chemical Conditions Affecting the Distribution of Aquatic Beetles : Lake of Sidi Boughaba as a Case Study (Kénitra, Morocco)
}

\section{Slim Mostafa ${ }^{1}$, Najoua Zouaki ${ }^{1}$, Hafsa Ouattar ${ }^{1}$, Dalale Mansouri ${ }^{1}$, Hmima Hajar ${ }^{1}$, Dounia Challi ${ }^{1}$, Hefdhallah Al-Aizari ${ }^{2,3^{*}}$, Fadli Mohamed ${ }^{1}$}

${ }^{1}$ Laboratory of Plant, Animal productions, and Agro-industry; Faculty of Sciences Kenitra, Ibn

Tofail University, B. 133 Kenitra (Morocco).

${ }^{2}$ Laboratory of Biotechnology, Environment and Quality - UFR of process engineering, Faculty

of Sciences, Ibn Tofail University, BP 133, Kenitra,(Morocco).

${ }^{3}$ Department of Chemistry, Faculty of Education, University of Dhamar, Yemen.

*Corresponding Author: alaizari2@gmail.com

\section{ARTICLE INFO}

Article History:

Received: May 9, 2021

Accepted: June 25, 2021

Online: July 5, 2021

\section{Keywords:}

Wetlands,

Aquatic beetles,

Ecology

Lake Sidi Boughaba

Physico-chemistry,

Morocco
ABSTRACT
Wetlands present an important diversity of life and are very productive. Many biotic and abiotic factors intervene in their functioning. Thus, understanding this functioning requires, among other characteristics, physicochemical characterizations of their waters and the determination of the specific structure of the stand that inhabits those environments. In this work, the authors were interested in the characterization of the waters of Lake Sidi Boughaba, wetland and biological reserve registered with the RAMSAR convention. This lake is made up of three parts of unequal volume and duration of flooding. The results showed that the studied living environment is very heterogeneous physicochemical and that from one biotope to another the values of the majority of the physicochemical parameters can vary from single, to double, to three times, and even more. Only the $\mathrm{pH}$, oxygen, and ammonium content are relatively stable. In addition, the results showed that the aquatic beetle population of the prospected environment consists of 34 species and subspecies, grouped into 9 systematic families and that the Dyticidae family and the Hydrophilidae family are the most represented. Likewise, the biotypological analysis of the population of beetles collected showed the distribution of the 34 inventoried species that are divided into four groups and that, among the 16 physicochemical parameters studied 10 intervene the determination of the specific structure of each of the groups of 'identified species.

\section{INTRODUCTION}

By ensuring the availability of water, biocenotic and biological diversity, wetlands are highly productive environments on the planet (Deák, et al., 2015). The functioning of these zones depends on many factors, in particular their hydrology, their physicochemical characteristics, the taxonomic structure, and the dynamics of their biocenoses (Gogoi et al., 2019). In Morocco, there are some 300 wetlands, some of which are included in the Ramsar convention. The Sidi Boughaba reserve (34 ${ }^{\circ} 12^{\prime} 56$ "and $34^{\circ} 15^{\prime \prime} 55$ "N latitude 
and $6^{\circ} 42^{\prime \prime} 32$ "and $6^{\circ} 45^{\prime} 27^{\prime \prime} \mathrm{W}$ longitude) is one. It is located $13 \mathrm{~km}$ from the center of the city of Kenitra in a depression in a hilly region (Fig. 1) near the Atlantic coast of northwest Morocco. It is made up of a forest environment centered by a lake that stretches $5.5 \mathrm{~km}$ in length and varies in width from 100 to 250 meters; the depth varies between 0.5 and 2.50 meters maximum (Slim et al., 2016). Likewise, this reserve is a biological reserve, included in the "Ramsar" list of wetlands, offering favorable conditions for the development of an important diversity of fauna. In addition, it is a point of passage, nesting, or hibernation for a large number of migratory birds and local birds (Lahrouz et al., 2011).Thus, numerous studies have indicated its great biological diversity, particularly those of Elkhiati et al. (2013), Cherkaoui et al. (2015) and Slim et al. (2019). Additionally, insects, larvae, and adults often constitute a large fraction of the population of macro-invertebrates in aquatic environments and many of them have potential indicators of the quality of the environment (Stein et al., 2008, Hauer \&Resh, 2017). They are also a food source for many vertebrates and several species of fish and play an important role in the trophic balance of their hydro-systems (Zha $\boldsymbol{e t}$ al., 2020). Therefore, it can be considered that for any aquatic ecosystem, determining the structure of the insect population constitutes a basis for estimating the quality and productivity of the environment. Thus, this study attempts to contribute to the Physico-chemical characterization of the environment and to identify the taxa of the beetle insect communities of Lake Sidi Boughaba which, under its location in an urban geographic area, is under various anthropogenic actions (Zha et al., 2020).

\section{MATERIALS AND METHODS}

\section{Study area}

Lake of Sidi Boughaba is limited to the north by the mouth of the Sebou wadi, and to the south by the marabout "Sidi Boughaba". Its formation is favored by the concave topographic surface of its site. Its water supply is provided by the coastal water table and runoff from the watershed. From north to south the lake is made up of three parts: a marshy area. It is fed by precipitation water and hardly persists for more than 6 months generally spread from the beginning of December to the beginning of May. A second part where water persists is the deepest points of relief and is fed by precipitation water and groundwater. A third part, more extensive, where the water is permanent and its supply is provided by the water table and precipitation water.

\section{Choice of stations and sampling of water and insects studied:}

The description of the aquatic environment studied focused on 8 stations (S1, S2, S3, S4, $\mathrm{S} 5, \mathrm{~S} 6, \mathrm{~S} 7$, and S8) distributed in such a way as to cover the main heterogeneity of the environment (Fig. $1 \&$ Table . 1). The choice of these stations took into account the duration of the impoundment of the site, the abundance of its aquatic vegetation, its depth, and the apparent degree of its salinity of the water. Thus, the 8 stations selected 
belong to various hydrological facies such as freshwater, saltwater, temporary water, and permanent water. In addition, in order to obtain comparable homogeneous data, each station was sampled during a period during which the majority of aquatic micro and macroinvertebrates are present; namely, April, May, and June. Moreover, it is this period that is characterized by hydrological stability. Note that this same study strategy has been adopted by other authors in the study of aquatic environments such as Frish et al. (2006) and Aoujdad et al. (2014).

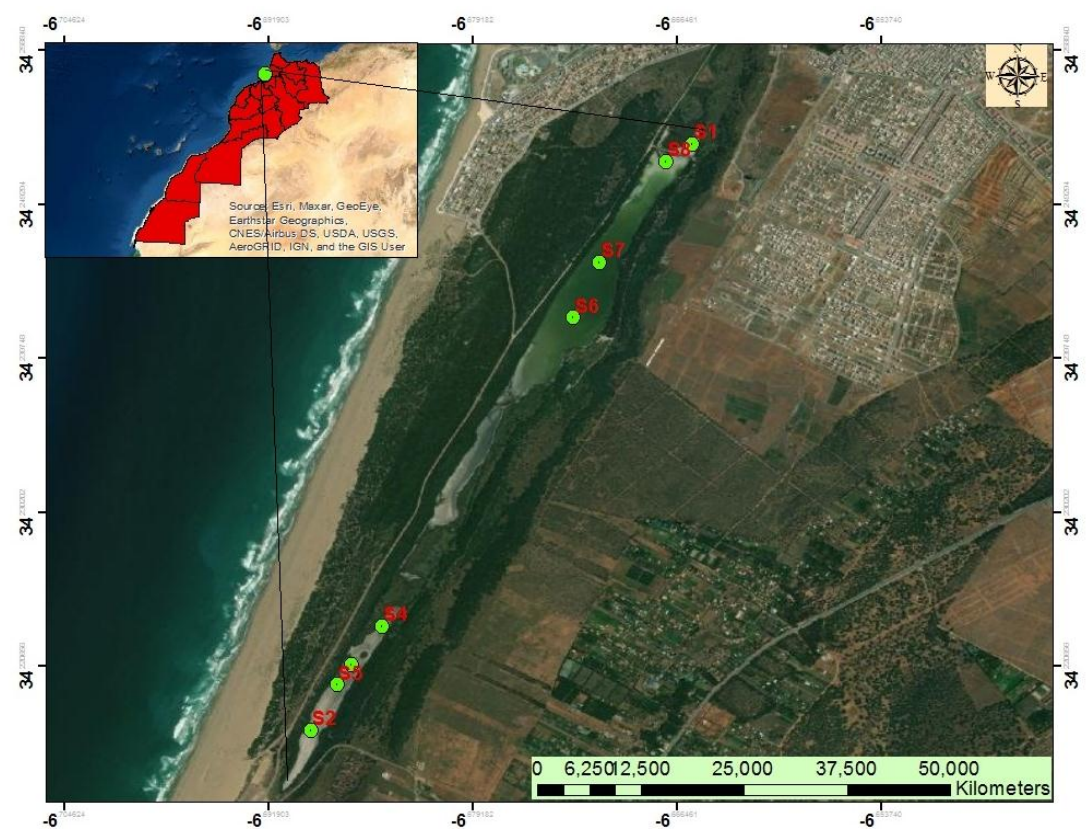

Fig. 1: Lake of Sidi Boughaba (Kenitra-Morroco)

Table 1: Main Characteristics of Surveyed Stations.

\begin{tabular}{lllllllll} 
Stations to prospect & S1 & S2 & S3 & S4 & S5 & S6 & S7 & S8 \\
\hline $\begin{array}{l}\text { Average filling time } \\
\text { (DME) (in months }\end{array}$ & 5 & 7 & 8 & 9 & 12 & 12 & 12 & 8 \\
\hline $\begin{array}{l}\text { The extent of } \\
\text { vegetation cover } \\
(\mathrm{CV})(\text { in\%) }\end{array}$ & 25 & 10 & 19 & 16 & 35 & 15 & 40 & 15 \\
\hline $\begin{array}{l}\text { Maximum depth } \\
\text { (Pmax) (in cm) }\end{array}$ & 60 & 95 & 50 & 80 & 300 & 230 & 240 & 146 \\
\hline
\end{tabular}

\section{METHODS AND MATERIEL}

This study aimed at three objectives: the determination of the specific structure of the population of aquatic Coleoptera insects, the physicochemical characterization of its waters, and the contribution to the determination of the physicochemical conditions 
which influence the ecology of the harvested species. At each of the stations studied, 16 physicochemical parameters were measured using electronic equipment or by volumetry. The temperature of the water was carried out using a mercury thermometer graduated in $1 / 10$ of a degree Celsius. The $\mathrm{pH}$ was carried out using an Orion Research, Ionalyser model $607 \mathrm{pH}$ meter with an Orion $\mathrm{pH}$ 91-05 specific electrode. The dissolved oxygen content was measured in the field using an ORION Research Pulse Oximeter, Ionalyser model 607 with specific $\mathrm{O} 2$ electrode. Additionally, conductivity was measured using a conductivity meter. The other chemical parameters were measured in the laboratory. Likewise, using a trouble net the authors swept several times and filtered the water at each of the stations surveyed, according to the chemical principles indicated by Rodier $\boldsymbol{e} t$ al. (2009). In addition, the qualitative sampling of the fauna studied was carried out using a troubleau net with an opening of $30 \mathrm{~cm}$ and a mesh size. Then, in the laboratory, the zoological content of each filtrum was sorted and systematically determined. Once the data was collected, a multivariate statistical analysis through the use of software, "Minitab" version 19 was performed.

\section{RESULTS AND DISCUSSION}

\section{The systematic structure of harvested aquatic beetles}

As shown in Table (2), the aquatic beetle population in the prospected environment consisted of 34 species and subspecies grouped into 9 systematic families. With 13 species and 11 species, the Dytiscidae family and the Hydrophilidae family were the most represented. In contrast, half of the families noted were represented by only one species each, in particular, the Hygrobiidae, Dryopidae, Noteridae, Helophoridae, and Gyrinidae families.

Table 2: Stationary Distribution of the Species Collected $(1=$ presence; $0=$ absence $)$

\begin{tabular}{llllllllll}
\hline Family & Species & S1 & S2 & S3 & S4 & S5 & S6 & S7 & S8 \\
\hline \hline $\begin{array}{l}\text { Gyrinidae } \\
\text { latreille, 1910 }\end{array}$ & Gyrinus dejeani & 1 & 1 & 1 & 1 & 1 & 1 & 1 & 1 \\
\cline { 2 - 9 } & $\begin{array}{l}\text { Peltodydes caesus } \\
\text { Haliplus }\end{array}$ & 1 & 1 & 1 & 1 & 1 & 1 & 1 & 1 \\
\hline \hline $\begin{array}{l}\text { Halipeaticollis } \\
\text { Aubé, 1936 }\end{array}$ & Haliplus guttatus & 1 & 1 & 1 & 1 & 1 & 1 & 1 & 1 \\
\hline \hline Hygrobiidae & Hygrobia tarda & 0 & 0 & 1 & 1 & 1 & 1 & 1 & 1 \\
\hline
\end{tabular}


Stimpson, 186

\begin{tabular}{lcccccccc}
\hline \begin{tabular}{l} 
Hyphydrus aubei \\
\hline $\begin{array}{l}\text { Hydrovatus } \\
\text { clypeal }\end{array}$
\end{tabular} & 1 & 1 & 1 & 1 & 1 & 0 & 0 & 1 \\
\hline $\begin{array}{l}\text { Guignotus } \\
\text { pusillus }\end{array}$ & 0 & 0 & 1 & 0 & 1 & 1 & 0 & 0 \\
\hline $\begin{array}{l}\text { Coelambus } \\
\text { parallelogrammus }\end{array}$ & 1 & 1 & 1 & 1 & 1 & 1 & 1 & 1 \\
\hline \hline $\begin{array}{l}\text { Hygrotus } \\
\text { inaequalis }\end{array}$ & 1 & 1 & 1 & 1 & 1 & 1 & 1 & 1
\end{tabular}

Dytiscidae Leach,
1815

\begin{tabular}{|c|c|c|c|c|c|c|c|c|c|}
\hline \multirow[t]{9}{*}{1815} & $\begin{array}{l}\text { Hydroporus } \\
\text { planus }\end{array}$ & 1 & 1 & 1 & 1 & 0 & 0 & 0 & 1 \\
\hline & $\begin{array}{l}\text { Laccophilus } \\
\text { minutes }\end{array}$ & 1 & 1 & 1 & 1 & 1 & 1 & 1 & 1 \\
\hline & $\begin{array}{l}\text { Methley } \\
\text { cribratellus }\end{array}$ & 0 & 0 & 0 & 0 & 1 & 1 & 1 & 0 \\
\hline & $\begin{array}{l}\text { Copelatus } \\
\text { atriceps }\end{array}$ & 1 & 1 & 1 & 1 & 1 & 1 & 1 & 1 \\
\hline & $\begin{array}{l}\text { Rhantus } \\
\text { hispanicus }\end{array}$ & 0 & 0 & 1 & 1 & 1 & 1 & 1 & 0 \\
\hline & Colymbetes fuscus & 0 & 0 & 1 & 1 & 1 & 1 & 1 & 0 \\
\hline & $\begin{array}{l}\text { Cybester } \\
\text { lateralimarginalis }\end{array}$ & 1 & 1 & 1 & 1 & 1 & 1 & 1 & 1 \\
\hline & $\begin{array}{l}\text { Cybester } \\
\text { tripunctatus }\end{array}$ & 1 & 1 & 1 & 1 & 1 & 1 & 1 & 1 \\
\hline & $\begin{array}{l}\text { Ochthebius } \\
\text { meridionalis }\end{array}$ & 1 & 1 & 1 & 1 & 1 & 1 & 1 & 1 \\
\hline $\begin{array}{l}\text { Hydraenidae } \\
\text { Mulsant, } 1844\end{array}$ & $\begin{array}{l}\text { Ochthebius } \\
\text { impressicollis }\end{array}$ & 1 & 1 & 1 & 1 & 1 & 1 & 1 & 1 \\
\hline \multirow[t]{4}{*}{$\begin{array}{l}\text { Helophoridae } \\
\text { Fabricius, } 1775\end{array}$} & $\begin{array}{l}\text { Helophorus } \\
\text { viridicollis }\end{array}$ & 1 & 1 & 1 & 1 & 1 & 1 & 1 & 0 \\
\hline & $\begin{array}{l}\text { Anacaena limbata } \\
\text { nitida }\end{array}$ & 0 & 0 & 0 & 1 & 1 & 1 & 1 & 0 \\
\hline & $\begin{array}{l}\text { Anacaena } \\
\text { globulus }\end{array}$ & 1 & 1 & 1 & 1 & 1 & 0 & 1 & 1 \\
\hline & $\begin{array}{l}\text { Enocrus } \\
\text { melanocephalus }\end{array}$ & 0 & 1 & 1 & 1 & 1 & 0 & 0 & 0 \\
\hline
\end{tabular}




\begin{tabular}{|c|c|c|c|c|c|c|c|c|c|}
\hline & \multicolumn{2}{|c|}{$\begin{array}{ll}\begin{array}{l}\text { Enochrus } \\
\text { coarctatus }\end{array} & 1 \\
\end{array}$} & 0 & 1 & 1 & 1 & 1 & 1 & 1 \\
\hline & $\begin{array}{l}\text { Hydrobius } \\
\text { convexus }\end{array}$ & 0 & 0 & 1 & 1 & 1 & 1 & 1 & 0 \\
\hline & Limnoxenus neger & 0 & 0 & 1 & 1 & 1 & 1 & 1 & 0 \\
\hline & Hydrous flavipes & 1 & 1 & 1 & 1 & 1 & 1 & 1 & 1 \\
\hline \multirow{3}{*}{$\begin{array}{l}\text { Hydrophilidae } \\
\text { Latreille, } 1802\end{array}$} & Hydrous pistaceus & 1 & 1 & 1 & 1 & 1 & 1 & 1 & 1 \\
\hline & Berosus affinis & 1 & 1 & 1 & 1 & 1 & 1 & 1 & 1 \\
\hline & $\begin{array}{l}\text { Berosus affinis } \\
\text { hispanicus }\end{array}$ & 1 & 1 & 1 & 1 & 1 & 1 & 1 & 1 \\
\hline $\begin{array}{l}\text { Dryopidae } \\
\text { Billberg, } 1820 \\
\end{array}$ & Dryops gracilis & 1 & 1 & 1 & 1 & 1 & 1 & 1 & 1 \\
\hline $\begin{array}{l}\text { Noteridae C. G. } \\
\text { Thomson, } 1860\end{array}$ & Noterus laevis & 1 & 1 & 1 & 1 & 1 & 1 & 1 & 1 \\
\hline $\begin{array}{l}\text { Richesse } \\
\text { spécifique }\end{array}$ & & 23 & 24 & 30 & 30 & 30 & 29 & 28 & 24 \\
\hline
\end{tabular}

\section{Spatial physicochemical variation of the studied medium}

The values of the measurements of the sixteen parameters evaluated are shown in Table (3). It was noticed that, the duration of the flooded phase of the environment studied varied according to the location of the station, from temporary, semi-temporary to permanent. The amount of plant covering the environment was not homogeneous and varied from 10 to $40 \%$, and the thickness of the water layer varied from 0.5 to $3 \mathrm{~m}$. The variation in maximum and minimum temperatures seems to be influenced by the depth of the medium. Generally, the $\mathrm{pH}$ is basic but it was less basic in the temporary parts of the lake than in its permanent or semi-permanent parts. The $\mathrm{EC}$ and contents of $\mathrm{Cl}^{-}, \mathrm{Ca}^{2+}$, $\mathrm{Mg}^{2+}$, dissolved oxygen, COD, and BOD5 varied greatly from one station to another. The variation was the same for nitrogenous substances.

Table 3: Specific Variation of the Values of the Physicochemical and Biological

Parameters.

\begin{tabular}{lllllllll}
\hline $\begin{array}{l}\text { Prospected } \\
\text { stations }\end{array}$ & S1 & S2 & S3 & S4 & S5 & S6 & S7 & S8 \\
\hline DME & 5 & 7 & 8 & 9 & 12 & 12 & 12 & 8 \\
\hline $\mathrm{CV}$ & 25 & 10 & 19 & 16 & 35 & 15 & 40 & 15 \\
\hline Pmax & 60 & 95 & 50 & 80 & 300 & 230 & 240 & 146 \\
\hline Tmin & 14.2 & 14 & 15 & 14 & 15 & 15.6 & 14.7 & 13 \\
\hline Tmax & 27.4 & 26 & 25 & 29 & 25 & 25 & 27 & 29 \\
\hline $\mathrm{pH}$ & 7.1 & 7.3 & 8.8 & 8.7 & 6.9 & 8.3 & 8.1 & 8.5 \\
\hline
\end{tabular}




\begin{tabular}{lllllllll}
\hline $\mathrm{EC}$ & 5500 & 4540 & 7950 & 7900 & 2800 & 3250 & 4560 & 4600 \\
\hline $\mathrm{Cl}^{-}$ & 510 & 493 & 4850 & 3930 & 992 & 1510 & 2121 & 3303 \\
\hline $\mathrm{Ca}^{2+}$ & 12.2 & 14 & 17.7 & 16.2 & 25 & 20.3 & 19.6 & 22.1 \\
\hline $\mathrm{Mg}^{2+}$ & 19.4 & 21 & 31 & 32.1 & 46 & 39.4 & 35.6 & 34 \\
\hline $\mathrm{OD}$ & 12.7 & 9.6 & 7.3 & 6.6 & 10.5 & 9.2 & 6.8 & 5.5 \\
\hline $\mathrm{DOC}$ & 71.5 & 102 & 151.3 & 121 & 89.8 & 127 & 120 & 99.4 \\
\hline $\mathrm{DBO}_{5}$ & 32.5 & 43.1 & 72 & 62.1 & 54.5 & 66.2 & 55 & 57.5 \\
\hline $\mathrm{NH}_{4}{ }^{+}$ & 1.21 & 1.17 & 3.1 & 2.95 & 1.74 & 1.24 & 0.98 & 0.93 \\
\hline $\mathrm{NO}_{3}{ }^{-}$ & 7.5 & 8.1 & 9.5 & 12.1 & 12.5 & 11.5 & 13.5 & 6.9 \\
\hline $\mathrm{NO}_{2}{ }^{-}$ & 0.15 & 0.31 & 0.95 & 1.11 & 1.15 & 0.64 & 0.36 & 0.19
\end{tabular}

Moreover, Raulings et al. (2010) and Schriever (2015) nd reported that, the abiotic environment has a strong influence on the ecology of the aquatic biocenosis. They added that, the hydroperiod and the size of the ponds had a strong influence on the invertebrate communities. However, for the majority of the variables measured, the degree of variation could be from simple to double. Similarly, with a specific respect to the chloride content, which is a determining factor for the quality and quantity of species and the specific structures of the populations in the environment (Ngugi et al., 2012). The values of certain stations were 4 to 9 times higher than the weakest ones. Roughly, the same is the case for many other estimated parameters. It should also be noted that, about the duration of the flooded phase, the stations studied were divided into three types of biotopes: temporary, semi-temporary, and permanent. However, according to numerous studies including those of Williams (1996) and Anusa et al. (2012), it should be noted that often, for the physicochemical parameters of the waters of the studied environment, the variation is inversely proportional to the duration of the flooded phase of the biotope.

\section{Typological and biotypological analysis of the environment}

\section{a. Assessment of the physico-chemical typology of the environment:}

The first three-factor axes together accumulated $83.6 \%$ of the total inertia (Table. 4 ). The two axes alone accumulated $70 \%$ or more than $50 \%$ of the cumulative information explaining the phenomenon studied. Thus, it was proposed to be satisfied with the physicochemical interpretation of the first two axes of $\mathrm{C} 1$ and $\mathrm{C} 2$ and of the plane of projection $\mathrm{C} 1 * \mathrm{C} 2$.

Table 4: Characteristics of the First Three Principal Components.

\begin{tabular}{llll}
\hline Eigenvalue & 6.0087 & 5.1892 & 2.1772 \\
\hline Proportion & 0.376 & 0.324 & 0.136 \\
\hline Cumulative & 0.376 & 0.7 & 0.836 \\
\hline
\end{tabular}


Table 5: Loadings of the Principal Components 1 and 2 of 16 Experimental Variables.

\begin{tabular}{lll}
\hline Variables & PC1 & PC2 \\
\hline DME & 0,352 & $-0,187$ \\
\hline EC & 0,13 & $-0,241$ \\
\hline Pmax & 0,234 & $-0,339$ \\
\hline Tmin & 0,238 & $-0,149$ \\
\hline Tmax & $-0,149$ & 0,177 \\
\hline $\mathrm{pH}$ & 0,181 & 0,348 \\
\hline $\mathrm{CD}$ & $-0,023$ & 0,398 \\
\hline $\mathrm{Cl}$ & 0,188 & 0,369 \\
\hline $\mathrm{Ca}^{-2}$ & 0,295 & $-0,16$ \\
\hline $\mathrm{Mg}^{2+}$ & 0,356 & $-0,15$ \\
\hline $\mathrm{OD}^{2+}$ & $-0,188$ & $-0,257$ \\
\hline $\mathrm{DCO}$ & 0,273 & 0,254 \\
\hline $\mathrm{DBO}^{+}$ & 0,347 & 0,197 \\
\hline $\mathrm{NH}_{4}{ }^{+}$ & 0,161 & 0,294 \\
\hline $\mathrm{NO}_{3}{ }^{-}$ & 0,317 & $-0,118$ \\
\hline $\mathrm{NO}_{2}{ }^{-}$ & 0,294 & 0,07 \\
\hline
\end{tabular}

Moreover, taking into account the importance of the explanatory inertia accumulated by the two axes $\mathrm{C} 1$ and $\mathrm{C} 2$ (70\%), the projection of the physicochemical variables, the stations, and the biological species collected in each of these stations allowed a statistical analysis showing the physico-chemical and biological diversity of the environment studied. This, in turn, would help to determine the environmental conditions that favor, or disadvantage, the presence of a particular species or associations of species. Thus, the analysis of Fig. (2) shows that, compared to the projection of the stations prospected on the axis $\mathrm{C} 1$, two groups of stations located on either side of the axis $\mathrm{C} 2$ and which vis-àvis the studied variables showed different characteristics:

- A first group G1 formed by stations S1, S2, and S8 are all located on the negative side of the $\mathrm{C} 1$ axis. This is stationed with a temporary to semi-temporary filling time. The values found for the constituent variables of this axis were lower than those noted for the second group of stations $\mathrm{G} 2$

- The second group of stations (G2) was located on the positive side of the C2 axis; namely, S3, S4, S5, S6, and S7. These are satiations whose impoundment was temporary, semi-temporary or permanent. The values found for the constituent variables of this axis were higher than those noted for the group of stations G1.

This same analysis showed that, with respect to the physicochemical gradient represented by the $\mathrm{C} 2$ axis, the $\mathrm{G} 1$ group could be subdivided into two subgroups (G1a and G1b), and the G2 group into two subgroups (G2a and G2b). Thus, the subgroups of stations G1a and $\mathrm{G} 2 \mathrm{a}$, unlike the subgroups $\mathrm{G} 1 \mathrm{~b}$ and $\mathrm{G} 2 \mathrm{~b}$, were characterized by $\mathrm{pH}$, electrical 
conductivities, high chloride, and ammonium concentrations, and plant cover, maximum temperatures and lower oxygen concentrations.

\section{b. Biotypological evaluation of collected beetles:}

The distribution of those species in relation to the stations was not homogeneous. The analysis of the projection of those species on the $\mathrm{C} 1 \mathrm{xC} 2$ plane (Fig. 3) contributes to the determination of the physicochemical conditions which could be responsible for the special distribution of the collected species. According to this analysis 4 groups of species could be differentiated:

- A first group G1 formed by stations S1, S2, and S8, which were all located on the negative side of the $\mathrm{C} 1$ axis. These were stations with a temporary to semi-temporary filling time. The values found for the variables constituting that axis were lower than those noted for the second group of stations G2

- The second group of stations (G2) was located on the positive side of the C2 axis; namely, S3, S4, S5, S6 and S7. These are satiations whose impoundment was temporary, semi-temporary, or permanent. The values found for the constituent variables of this axis were higher than those noted for the group of stations G1; For the biotypology distribution of the species collected (Fig. 3), the analysis shows the differentiation of 4 subgroups G1a, G1b, G2a, and G2b:

Biplot of Variables

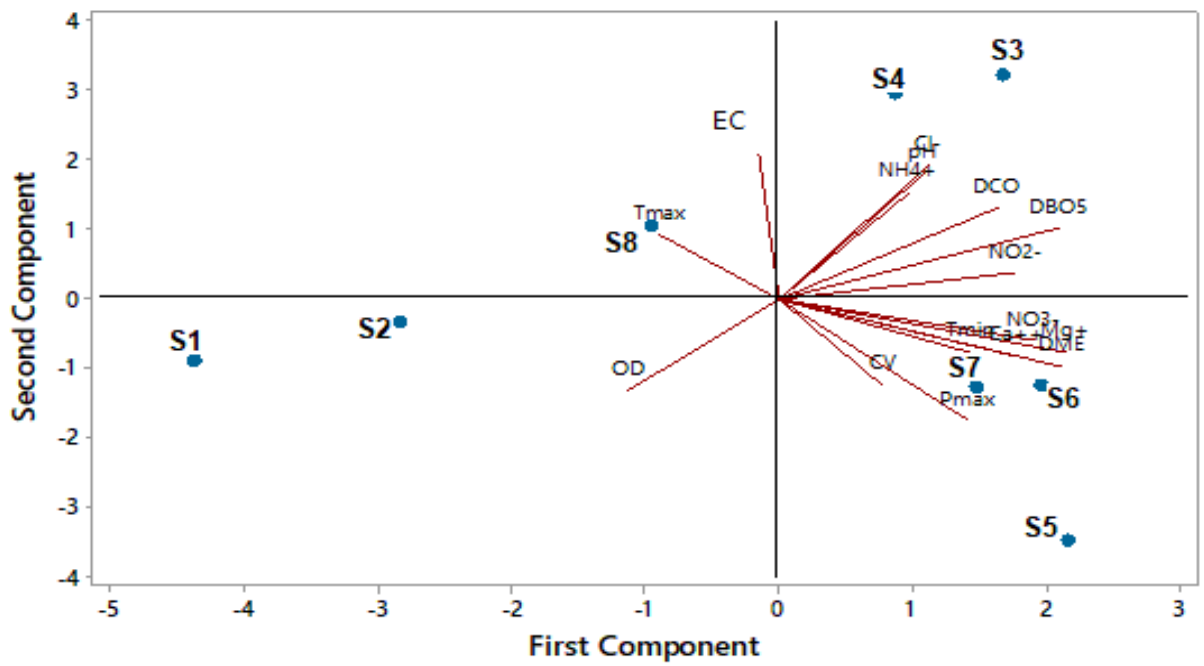

Fig. 2: Projection of the Points Representing the Stations Prospected and the Physicochemical Parameters Studied. 


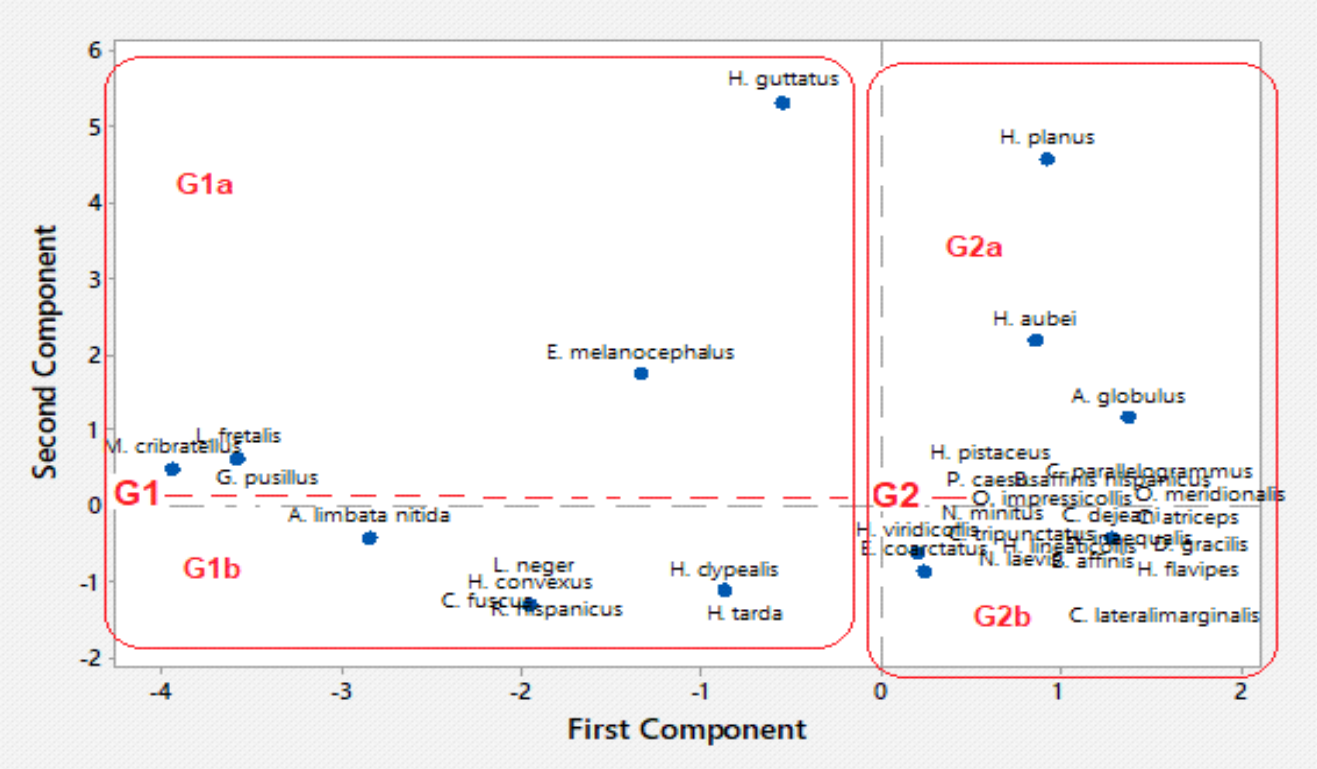

Fig. 3: Distribution of Species about the Surveyed Stations.

\section{Species group G1a}

Species requiring or preferring living environments with temporary to semi-temporary impoundment, relative to the physico-chemical conditions were prevailing in the studied environment. The values found for the minimum temperature, the contents of $\mathrm{Ca}^{2+}, \mathrm{Mg}^{2+}$, BOD, nitrates, nitrites and dissolved oxygen were low. Likewise, the degree of plant cover in the medium and the maximum water temperature was low, while the values of $\mathrm{pH}, \mathrm{EC}$, and concentrations of $\mathrm{Cl}^{-}$and $\mathrm{NH}^{+}$were high.

Examples: $H$. guttate and E. melanocephalus

\section{Species group G1b}

As for the group of species G1a, the living environment of the group species was temporary to semi-temporary impoundment and characterized by minimum water temperature, the contents of $\mathrm{Ca}^{2+}, \mathrm{Mg}^{2+}, \mathrm{BOD}$, nitrates, nitrites and dissolved oxygen were low. However, the degree of vegetation cover in the medium and the maximum water temperature was high, while the values of $\mathrm{pH}, \mathrm{EC}$, and concentrations of $\mathrm{Cl}^{-}$and $\mathrm{NH} 4^{+}$were low. Examples: H. dypealis and H. Tarda.

\section{Species group G2a}

The living environment of this group was with temporary to semi-temporary impoundment. The values found for the variables constituting this axis were higher than those noted for the second group of stations G2a and G2b; namely, Tmin, $\mathrm{Ca}^{2+}, \mathrm{Mg}^{2+}$, $\mathrm{BOD}$, nitrates, and high nitrates. The values of $\mathrm{pH}, \mathrm{EC}, \mathrm{Cl}^{-}$and ammonium were also high while CV, Tmax, OD were low.

Examples: $H$. planus and $H$. aubei 


\section{Species group G2b}

The living environment housing this group of species was temporary, semi-temporary or permanent. The values found for Tmin, $\mathrm{Ca}^{2+}, \mathrm{Mg}^{2+}, \mathrm{BOD}$, nitrates, and nitrites were high. Moreover, CV, Tmax, OD were also high while the values of $\mathrm{pH}, \mathrm{EC}, \mathrm{Cl}^{-}$, and $\mathrm{NH}_{4}^{+}$ were low.

\section{Examples : H. flavipes and C. laterimarginalis}

In addition, the importance of the flooded phase of the biotope, the local physicochemical conditions and the richness of the environment in aquatic plants seem to be the main cause of the physico-chemical heterogeneity of the studied environment. It is worthy to mention that, Schriever (2015) stated that, there are biotic interactions and species life cycles that interact with abiotic factors.

Indeed, according to Williams (1996), the aquatic insects which live in these habitats are strongly influenced by physicochemical factors and the duration of the flooded phase of the biotope. Likewise et al. (2012) and Schriever (2015) added an effect of the area and depth of the biotope on the diversity of species and the physicochemical characteristics of habitats.

\section{CONCLUSION}

From a physicochemical point of view, the studied environment revealed to be very heterogeneous. From one biotope to another, for most of those parameters, the coefficient of variation could be double, quadruple, or even more. The authors cited the duration of the flooded phase of the studied environment which, from one biotope to another, could be temporary, semi-temporary, or permanent; the importance of the plant cover of the environment varied from 10 to $40 \%$, the water depth varied from 0.5 to $3 \mathrm{~m}$ and the $\mathrm{Cl}$ content (very determining ecological factor in the ecology of the species) from 493mg / 1 to $4850 \mathrm{mg}$. Only the $\mathrm{pH}$, the dissolved oxygen content and the $\mathrm{NH}^{+}$content were relatively stable. Moreover, the biotypological estimate of the species showed a distinction of 4 groups of species G1a, G2a, Gab, and G2b. Among the sixteen estimated variables, 10 variables intervened by the combination of their values in the specific structure constituting each group of species; namely, the duration of watering of the biotope, the importance of plant cover and conductivity, the $\mathrm{pH}$, the temperature, and the contents of $\mathrm{Mg}^{2+}, \mathrm{Ca}^{2+}, \mathrm{NH} 4^{+}$and DO.

\section{REFERENCES}

Anusa, A.; Ndagurwa, H. G. T. and Magadza, C. H. D. (2012). The influence of pool size on species diversity and water chemistry in temporary rock pools on Domboshawa Mountain, northern Zimbabwe. African Journal of Aquatic Science., 37(1): 89-99. 
Aoujdad, R.; Maqboul, A.; Fadli, M. and Fekhaoui, M. (2014). Structure and organization of the crustaceans cladoceran populations in Moroccan rice fields. J Entomol Zool Stud., 2(6): 39-44.

Cherkaoui, S. I.; Hanane, S.; Magri, N.; El Agbani, M. A. and Dakki, M. (2015). Factors influencing species-richness of breeding waterbirds in Moroccan IBA and Ramsar wetlands: a macroecological approach. Wetlands., 35(5): 913-922.

Deák, B.; Valkó, O.; Török, P.; Kelemen, A.; Tóth, K.; Miglécz, T. and Tóthmérész, B. (2015). Reed cut, habitat diversity and productivity in wetlands. Ecological Complexity., 22: 121-125.

Elkhiati, N.; Ramdani, M.; Espinar Rodríguez, J. L.; Fahd, K.and Serrano Martín, L. (2013). Ecological similarities between two Mediterranean wetlands: Sidi Boughaba (north-west Morocco) and the Doñana National Park (south-west Spain). Journal of Limnology., 72 (2): 301-312.

Frisch, D.; Moreno-Ostos, E. and Green, A. j. (2006). Species richness and distribution of copepods and cladocerans and their relation to hydroperiod and other environmental variables in Donana, southwest Spain. Hydrobiologia., 556: $327-$ 340.

Gogoi, P.; Sinha, A.; Sarkar, S. D.; Chanu, T. N.; Yadav, A. K.; Koushlesh, S. K. and Das, B. K. (2019). Seasonal influence of physicochemical parameters on phytoplankton diversity and assemblage pattern in Kailash Khal, a tropical wetland, Sundarbans, India. Applied Water Science., 9(7): 1-13.

Hauer, F. R. and Resh, V. H. (2017). Macroinvertebrates. In Methods in Stream Ecology. Academic Press., 1 ( 1): 297-319.

Lahrouz, S. A. I. D.; Dakki, M. and Gmira.N. (2011). Le marécage de Fouwarate (Kenitra, Maroc): site de conservation d'oiseaux menacés par l'urbanisation. Afrique Science: Revue Internationale des Sciences et Technologie., 7(1) : 65-76.

Ngugi, D. K.; Antunes, A.; Brune, A. and Stingl, U. (2012). Biogeography of pelagic bacterioplankton across an antagonistic temperature-salinity gradient in the Red Sea. Molecular Ecology., 21(2): 388-400.

Raulings, E. J.; Morris, K. A. Y.; Roache, M. C. and Boon, P. I. (2010). The importance of water regimes operating at small spatial scales for the diversity and structure of wetland vegetation. Freshwater Biology., 55(3): 701-715.

Rodier, J.; Legube, B. and Merlet, N. (2009). Water analysis. 9th edition fully updated. Dunod paris, $1526 \mathrm{p}$.

Schriever, T. A. (2015). Food webs in relation to variation in the environment and species assemblage: a multivariate approach. PloS one., 10(4): e0122719.

Slim, M.; Zouaki, N. and Fadli, M. (2019). A comparative study of the Coleoptera biodiversity of three areas of the Gharb plain: The biological reserve of Sidi 
Boughaba, the Mamora forest, and the merja of Fouarat. Journal of Entomology and Zoology Studies., 7(1): 853-860.

Slim, M.; Zouaki, N.; Lougraimzi, H.; Elghali, L.; Zidane, L. and Fadli, M. (2016). Diversity, Composition and Systematic Structure of the Terrestrial Entomofauna of a Ramsar site: The Biological Reserve of Sidi Boughaba, Mehdia (Morocco). J Entomol Zool Stud., 4(4):705-712.

Stein, H.; Springer, M. and Kohlmann, B. (2008). Comparison of two sampling methods for biomonitoring using aquatic macroinvertebrates in the Dos Novillos River, Costa Rica. Ecological Engineering., 34(4): 267-275.

Williams, D. D. (1996). Environmental constraints in temporary freshwaters and their consequences for the insect fauna. Journal of the North American Benthological Society., 15(4): 634-650.

Zhai, M.; Syrovátka, V.; Bojková, J.; Šorfová, V.; Polášková, V.; Schenková, J., and Horsák, M. (2020). Does predator abundance influence species diversity of equilibrium macroinvertebrate assemblages in spring fens?. Freshwater Biology., 65(5): 987-998. 